\title{
Changes in herbivore control in arable fields by detrital subsidies depend on predator species and vary in space
}

\author{
Karsten von Berg $\cdot$ Carsten Thies $\cdot$ Teja Tscharntke $\cdot$ \\ Stefan Scheu
}

Received: 22 December 2008 / Accepted: 3 March 2010 / Published online: 28 March 2010

(C) The Author(s) 2010. This article is published with open access at Springerlink.com

\begin{abstract}
Prey from the decomposer subsystem may help sustain predator populations in arable fields. Adding organic residues to agricultural systems may therefore enhance pest control. We investigated whether resource addition (maize mulch) strengthens aboveground trophic cascades in winter wheat fields. Evaluating the flux of the maize-borne carbon into the food web after 9 months via stable isotope analysis allowed differentiating between prey in predator diets originating from the above- and belowground subsystems. Furthermore, we recorded aphid populations in predator-reduced and control plots of no-mulch and mulch addition treatments. All analyzed soil dwelling species incorporated maize-borne carbon. In contrast, only 2 out of 13 aboveground predator species incorporated maize carbon, suggesting that these 2 predators forage on prey from the above- and belowground systems. Supporting this conclusion, densities of these two predator species were increased in the mulch addition fields. Nitrogen isotope signatures suggested that these generalist predators in part fed on Collembola thereby benefiting indirectly from detrital resources. Increased density of these two predator
\end{abstract}

Communicated by Roland Brandl.

K. von Berg

Animal Ecology, Darmstadt University of Technology,

Schnittspahnstr. 3, 64287 Darmstadt, Germany

C. Thies $\cdot$ T. Tscharntke

Agroecology, Georg-August-University Göttingen,

Waldweg 26, 37073 Göttingen, Germany

S. Scheu $(\square)$

Johann Friedrich Blumenbach Institute of Zoology

and Anthropology, Georg-August-University Göttingen,

Berliner Str. 28, 37073 Göttingen, Germany

e-mail: sscheu@gwdg.de species was associated by increased aphid control but the identity of predators responsible for aphid control varied in space. One of the three wheat fields studied even lacked aphid control despite of mulch-mediated increased density of generalist predators. The results suggest that detrital subsidies quickly enter belowground food webs but only a few aboveground predator species include prey out of the decomposer system into their diet. Variation in the identity of predator species benefiting from detrital resources between sites suggest that, depending on locality, different predator species are subsidised by prey out of the decomposer system and that these predators contribute to aphid control. Therefore, by engineering the decomposer subsystem via detrital subsidies, biological control by generalist predators may be strengthened.

Keywords Food web · Energy subsidy · Pest control · Aphids $\cdot$ Stable isotopes

\section{Introduction}

Generalist predators, including carabids, staphylinids and spiders, are among the most important predators in terrestrial arthropod systems. They effectively decrease prey populations including agricultural pest species (Wise 1993; Lövei and Sunderland 1996; Symondson et al. 2002). Due to their catholic feeding, they may lack attributes of the ideal biological control agent such as prey specialisation. However, including non-pest prey in their diet may sustain generalist predator populations in fields when pest prey is scarce (Symondson et al. 2002), an important feature lacking in specialists. Periodic feeding by generalist predators on alternative prey from the detrital subsystem may strengthen herbivore control through apparent competition 
(Polis 1994; Polis and Strong 1996; Scheu 2001; Bell et al. 2008). Decomposer organisms generally appear to be limited by the availability of dead organic matter (Hairston et al. 1960; Hairston 1989; Scheu and Schaefer 1998), and therefore the detrital food web may be manipulated through application of allochthonous resources.

There is evidence that fostering the decomposer subsystem through detrital subsidies may increase densities of generalist predators in rice (Settle et al. 1996) and vegetable garden systems (Halaj and Wise 2002). However, increased densities of generalist predators may also enhance intraguild predation and cannibalism. Both are common in terrestrial food webs (Polis et al. 1989; 1991) and have been suggested to dampen biological control (Snyder and Wise 2001; Lang 2003; Wise 2006). Further, generalist predators may not switch to pest species if alternative prey is in ample supply (Birkhofer et al. 2008). Especially aphids are of low food quality or even toxic for generalist predators (Toft 2005; Oelbermann and Scheu 2002), possibly preventing generalist predators from including these pest species in their diet. For a better understanding of the factors affecting pest suppression, information on trophic links and food web structure above- as well as belowground of arable systems is needed.

The analysis of natural variations in stable isotope ratios is a promising tool to investigate trophic interrelationships, especially in food webs where generalist predators dominate (Ponsard and Arditi 2000; Scheu and Falca 2000; Scheu 2002). The concentration of ${ }^{15} \mathrm{~N}$ in consumers increases at higher trophic levels and this allows determining the trophic position of species in food webs (DeNiro and Epstein 1981; Minagawa and Wada 1984; Post 2002). In contrast to ${ }^{15} \mathrm{~N}$, carbon isotopes are little fractionated in consumers (Peterson and Fry 1987; Post 2002) and allow the determining of food resources of consumers. Differences in carbon isotope ratios of resources have been used to trace carbon fluxes and determine the fractions of different food sources in animal diets (Fry et al. 1978; Martin et al. 1992; Pollierer et al. 2007). C4 and C3 plants markedly differ in their ${ }^{13} \mathrm{C} /{ }^{12} \mathrm{C}$ ratio and maize ( $\mathrm{C} 4$ plant) as a food resource for the decomposer subsystem has been used before to trace carbon fluxes into the soil food web of arable systems (Albers et al. 2006). They found the maize carbon to be rapidly incorporated into the decomposer system; however, further carbon fluxes into the aboveground subsystem were not evaluated.

In the present study, we investigated the effect of detrital subsidies (maize mulch) on the decomposer subsystem and its feedbacks on the aboveground generalist predatorherbivore system in winter wheat. To consider variations in predator-prey relationships in space three wheat fields embedded in different landscapes were investigated. We hypothesised that (1) an allochthonous resource (maize mulch) boosts decomposer densities with effects propagating into the next growing season; (2) generalist predators feed on prey from the decomposer subsystem, resulting in increased predator densities in mulched fields and as a consequence, (3) to increased suppression of herbivore populations.

\section{Materials and methods}

\section{Study site}

The experiment was conducted between September 2003 and August 2004 in three winter wheat fields managed by the Reinshof research farm of the University of Göttingen (Lower Saxony, Germany). Two of the three investigated fields were located near the River Leine at $150 \mathrm{~m}$ above sea level. Field 1 was surrounded by cereal and root crop fields; field 2 was close to the city of Göttingen, adjacent to a garden colony. At these sites, loamy flood-plain soils established on clayey silt predominate. Field 3 was located in the north of Göttingen at $320 \mathrm{~m}$ above sea level; the soil at this site was shallow (Rendzina) and formed on shell limestone. It was surrounded by hedgerows and groves, embedded in a diverse landscape of a mixture of forests, hedgerows, and pastures. The mean annual temperature in Göttingen is $8.7^{\circ} \mathrm{C}$, and the mean annual precipitation is $645 \mathrm{~mm}$. Mean temperature was higher than average during both years of the study, mean rainfall was lower in 2003 and higher in 2004 than average $\left(9.4^{\circ} \mathrm{C}\right.$ and $550 \mathrm{~mm}$ in $2003,9.1^{\circ} \mathrm{C}$ and $718 \mathrm{~mm}$ in 2004).

Experimental setup and sampling

In each field, two randomly chosen areas of 1 ha each received $15 \mathrm{t}$ (fresh weight) of maize chaff in September 2003. The maize chaff was equally distributed within the 1 ha areas and homogenised with the upper soil layer by grubbing. Subsequently, all three fields including the mulched areas were sown with winter wheat. In May 2004, experimental treatments were established in a $2 \times 2 \times 2$ factorial design with the factors 'mulch' (with and without), 'soil dwelling predators' (SP, reduced and open control) and 'flying predators' (FP, reduced and open control) with two replicates per field. To reduce soil dwelling predators, plastic barriers were installed reaching $10 \mathrm{~cm}$ into the soil and $40 \mathrm{~cm}$ above the ground enclosing a circular area of $2 \mathrm{~m}^{2}$. Four 'live' pitfall traps (without trapping liquid) situated at the inner edge of the barriers were established in a cross design. Pitfalls were cleared daily over a period of 19 days throughout June. All predators, i.e. carabid and staphylinid beetles, and lycosid spiders, were visually identified, counted and released outside the plots. All other 
animals were returned to the plots. To reduce flying aphid predators and parasitoids, wire cages (mesh size $8 \mathrm{~mm}$ ) were set over the plots at the end of June. Cages were sprayed with non-toxic glue (Soveurode Aerosol, Witasek, Austria) to capture flying arthropods.

In each plot, one pot (diameter $25 \mathrm{~cm}$, height $25 \mathrm{~cm}$ ) planted with wheat of the same variety as in the fields was buried with the edging of the pot at ground level enabling access by surface-active arthropods. The pots were established to test for indirect mulch effects on aphid population development via changing predator control; direct effects due to mulch-mediated changes in nutrient availability were excluded by filling the pots uniformly with soil from the respective non-mulch fields. Aphids were counted visually on 25 wheat shoots inside and outside the pot at milk ripening in mid-July.

To determine the densities of soil dwelling arthropods, including generalist predators and surface active Collembola, plastic barriers as described above were installed in each of the three fields in both the mulch and no-mulch treatments and replicated four times. Four pitfall traps containing an oversaturated saltwater solution were established in a cross design at the inner edge of the barriers. Placing pitfall traps inside the fenced plots allowed taking the catches as density measures as the specimens were caught from a fixed area. However, the catches also reflect the activity of the species caught and more active species therefore may be over-represented. The pitfall traps operated for 2 weeks on three dates, respectively (May 26-June 9, June 23-July 7, July 21-August 4). When pitfall traps were not operating they were closed and the plastic barriers were lifted $15 \mathrm{~cm}$ above ground to enable recolonisation by arthropods. Additionally, one soil core (diameter $21 \mathrm{~cm}$ ) adjacent to each of the plots was taken at the same dates pitfall traps were opened. Soil animals were extracted from the upper $10 \mathrm{~cm}$ of the soil cores by heat (Kempson et al. 1963). Invertebrates from the pitfall traps as well as from the soil cores were determined to genus or species level, counted, and stored in oversaturated saltwater solution at $-10^{\circ} \mathrm{C}$ until they were processed for stable isotope analysis.

${ }^{13} \mathrm{C}$ and ${ }^{15} \mathrm{~N}$ analysis

Wheat plants from the experimental plots as well as maize chaff were dried at $60^{\circ} \mathrm{C}$ for 2 days, ground and dried again at $60^{\circ} \mathrm{C}$ for 1 day. Samples of $\sim 2.6 \mathrm{mg}$ dry mass were prepared for ${ }^{13} \mathrm{C}$ and ${ }^{15} \mathrm{~N}$ analysis. Animals were washed in distilled water and dried at $60^{\circ} \mathrm{C}$ for 6 days. Either homogenised animal tissue or whole animals $(80-1,660 \mu \mathrm{g})$ were used for stable isotope analysis. In mesofauna species, two or more specimens were bulked per sample to reach appropriate sample weight. Samples were kept in a desiccator until mass spectrometer analysis.

Samples were analysed by a coupled system consisting of an elemental analyser (NA 1500; Carlo Erba, Milan, Italy) and a gas isotope mass spectrometer (MAT 251; Finnigan, Bremen, Germany). The system is computer controlled allowing online measurement of ${ }^{13} \mathrm{C}$ and ${ }^{15} \mathrm{~N}$ (Reineking et al. 1993). As primary standards for the isotope values of carbon and nitrogen, Pee Dee Belemnite (PDB) limestone and atmospheric air were used, respectively. Acetanilide (Merck, Darmstadt, Germany) was used for internal calibration. Isotope natural ratios were expressed using the delta notation with $\delta^{13} \mathrm{C}$ or $\delta^{15} \mathrm{~N}(\% o)=\left(R_{\text {sample }}-\right.$ $\left.R_{\text {standard }}\right) /\left(R_{\text {standard }} \times 1,000\right)$, where $R_{\text {sample }}$ and $R_{\text {standard }}$ represent the ${ }^{13} \mathrm{C}$-to- ${ }^{12} \mathrm{C}$ or ${ }^{15} \mathrm{~N}$-to- ${ }^{14} \mathrm{~N}$ ratio in samples and standard, respectively. Incorporated maize-borne carbon in animals tissue $\left(x_{\mathrm{m}}\right)$ was calculated by a two-source mixing model with $x_{\mathrm{m}}(\%)=\left(\delta_{\mathrm{am}}-\delta_{\mathrm{aw}}\right) /\left(\delta_{\mathrm{pm}}-\delta_{\mathrm{pw}}\right) \times 100 ; \delta_{\mathrm{am}}$ and $\delta_{\text {aw }}$ refer to the $\delta^{13} \mathrm{C}$ signature of an animal species in the plots with and without maize-mulch, respectively, and $\delta_{\mathrm{pm}}$ and $\delta_{\mathrm{pw}}$ to the $\delta^{13} \mathrm{C}$ signature of the maize-mulch and the wheat plants, respectively.

\section{Statistical analysis}

Data on densities of soil dwelling predator and Collembola species were analyzed by repeated measures (RM) ANOVA with the fixed factors 'field' $(1,2,3)$ and 'mulch' (with, without), and the three consecutive sampling dates as repeated factor. Univariate analyses were performed to inspect interactions if significant in RM-MANOVA and because RM-MANOVA is less powerful than the univariate counterpart for small sample size (Cole and Grizzle 1966; Potvin et al. 1990). Within-subject probabilities were Huynh-Feldt corrected as this adjustment performs well in terms of type I error and power (Stiger et al. 1998) and is recommended by Potvin et al. (1990). In case of significant interactions between one or both of the fixed factors and sampling date, two-factor ANOVA was used to analyse the effects of 'field' and/or 'mulch' at separate sampling dates. Where appropriate, Bonferroni-corrected post hoc tests were performed to identify differences between treatments.

Data on aphid densities were analysed by analysis of variance (ANOVA) with the dependent variable 'aphids' (numbers per shoot) and the independent variables 'pot' (yes, no), 'field' (1, 2, 3), 'mulch' (with, without), 'soil dwelling predators' (SP, reduced and control) and 'flying predators' (FP, reduced and control). Data were square root transformed prior to the analyses.

Data on $\delta^{15} \mathrm{~N}$ and $\delta^{13} \mathrm{C}$ signatures were analysed by single factor ANOVAs with the independent variable 'mulch' using the GLM procedure to account for unequal cell sizes. 
Statistical analyses were performed using Statistica 7.1 (StatSoft, Tulsa, USA).

\section{Results}

Soil animals

From soil cores, the following species were extracted: Pergamasus sp. Berlese (Mesostigmata); Blaniulus guttulatus F. (1798), Brachyiulus pusillus Leach (1815), Polydesmus inconstans Latzel (1884) (Diplopoda); Lithobius microps Meinert (1868), Necrophloeophagus longicornis Leach (1858) (Chilopoda); Symphyla; Onychiurus spp. Gervais (1841) (Collembola); elaterid larvae (Coleoptera); sciarid larvae and tipulid larvae (Diptera). Densities of all these taxa were too low for statistical analysis, therefore individuals from the different sampling dates were pooled and used for stable isotope analysis.

\section{Predators}

With the 'live' pitfall traps, 728 staphylinids, 376 carabids and 87 lycosids were removed from the reduced soil-dwelling predator and the reduced flying- and soil-dwelling predator treatments during 19 days in June. On average, ratios between predator numbers removed from mulch and no-mulch plots were $64: 36$ for rove beetles, $60: 40$ for carabid beetles and 31:69 for lycosids.

Fig. 1 Mean population densities $[($ numbers +1$) \pm$ SE per $2 \mathrm{~m}^{2}$; note log-scale] of soil surface-dwelling generalist predators $(\mathbf{a}-\mathbf{f})$ and epigeic

Collembola captured by pitfall traps $(\mathbf{g}-\mathbf{i})$ in no-mulch (open circle with lines) and mulch (filled circle with lines) treatments in the three different fields at three consecutive sampling dates (June 9, July 7, August 4). Significant differences between means of no-mulch and mulch treatments are marked by asterisks $(* P<0.05$, $* * P<0.01, * * * P<0.001$; one-way ANOVAs following RM-ANOVAs, see text for details)
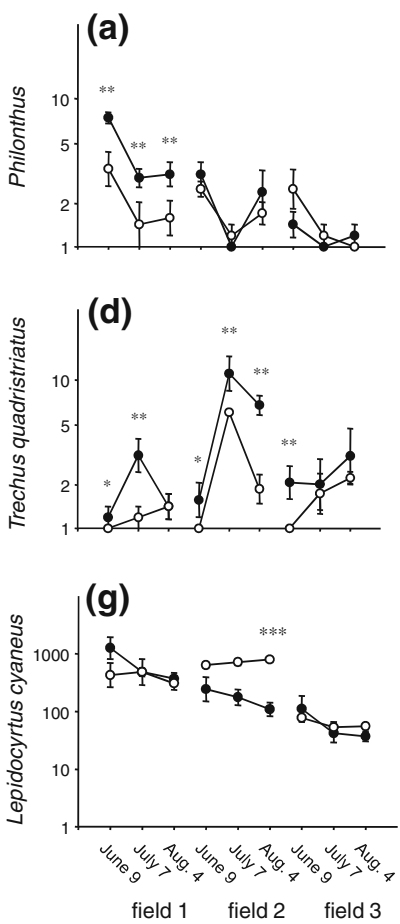

With the saltwater-filled pitfall traps, 1,094 carabids (34 species), 180 carabid larvae, 509 staphylinids (12 genera) and 353 staphylinid larvae (5 subfamilies) were captured. As staphylinids were affected by sampling date, field and mulch (RM-ANOVA; $F_{4,36}=3.34, P=0.019$ for date $\times$ field $\times$ mulch) and carabids by sampling date and field (RM-ANOVA; $F_{4,36}=11.09, P<0.001$ for date $\times$ field), RM-ANOVAs were calculated for the most abundant staphylinid and carabid species.

In staphylinids densities of Philonthus spp. (mainly $P$. fuscipennis) were significantly higher in the mulch treatment in field 1 at all three sampling dates (RM-ANOVA; $F_{2,18}=7.20, P=0.005$ for field $\times$ mulch; Fig. 1a). Densities of Oxytelus inustus were significantly higher in the mulch treatment in fields 2 and 3 at the first sampling date and in the mulch treatment in field 3 at the second sampling date (RM-ANOVA; $F_{2,36}=5.47, P=0.008$ for date $\times$ mulch; Fig. 1b). Densities of staphylinid larvae were significantly increased in the mulch treatment in each of the fields at the second sampling date (RM-ANOVA; $F_{4,36}=7.36$, $P<0.001$ for date $\times$ field; Fig. 1c).

In carabids, densities of Trechus quadristriatus were significantly higher in the mulch treatments in all fields at the first and second sampling date (RM-ANOVA; $F_{4,36}=2.73$, $P=0.044$ for date $\times$ field $\times$ mulch; Fig. 1d); at the third sampling date, densities were still significantly higher in the mulch treatment but only in field 2. Densities of Notiophilus biguttatus, Notiophilus palustris, Loricera pilicornis (Carabidae) and Stenus sp. (Staphylinidae) were pooled as

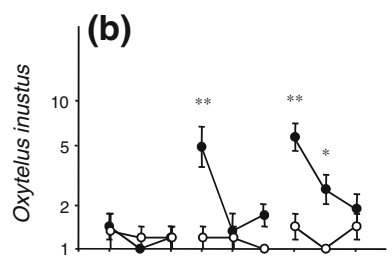

(e)
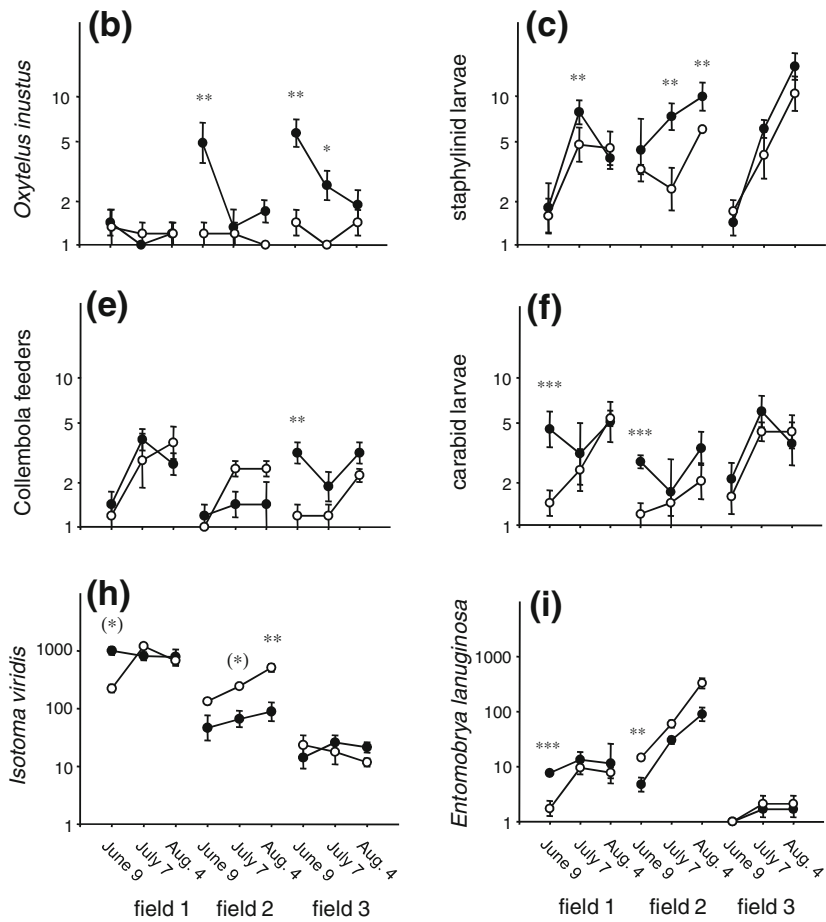
Fig. 2 Mean $\delta^{15} \mathrm{~N}$ values and fraction of maize-borne carbon in the body tissue (\% of total, black pie) of soil dwelling taxa captured by heat extraction which incorporated maize carbon (means with SD given below taxon name). The lower dashed line represents the $\delta^{15} \mathrm{~N}$ value of maize, the upper dashed line the assumed threshold of the second trophic level

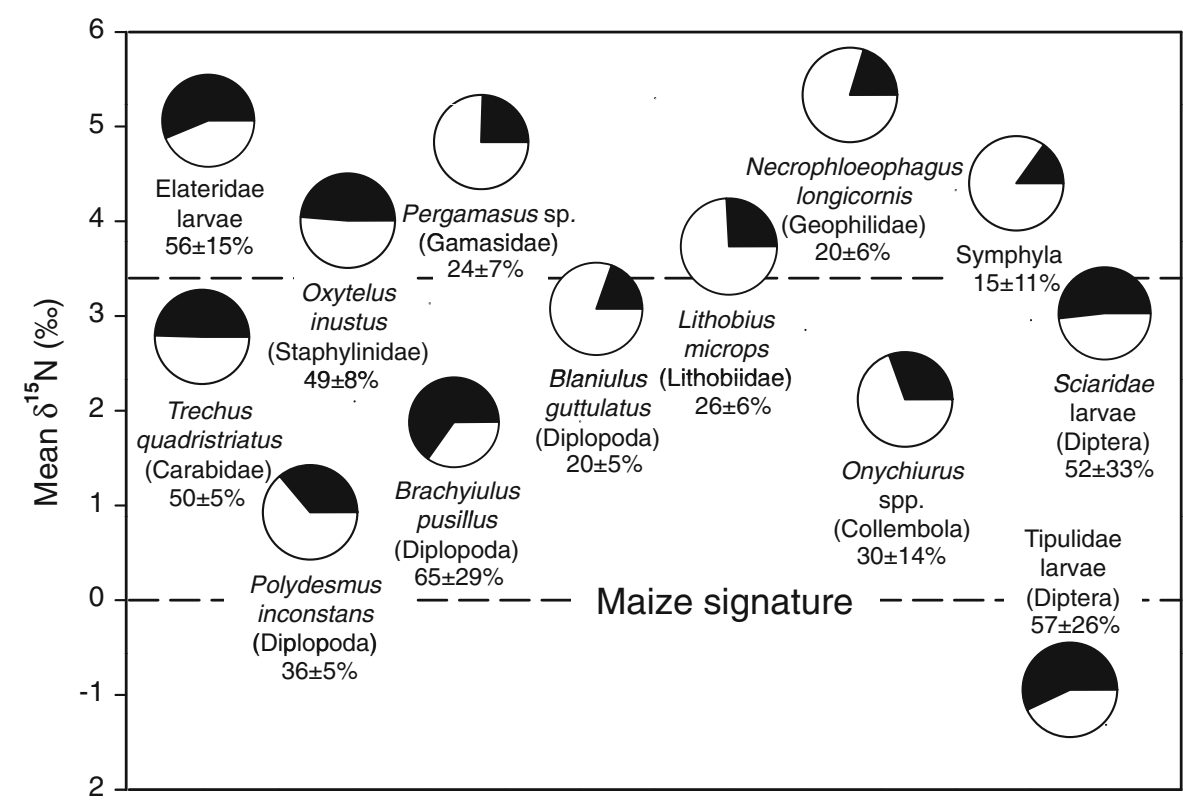

'Collembola feeders' (Weinreich 1968; Thiele 1977). These were enhanced significantly in the mulch treatment in field 3 (RM-ANOVA; $F_{2,36}=3.61, P=0.037$ for date $\times$ mulch; Fig 1e). Abundances of carabid larvae were significantly higher in mulch plots in all three fields at the first sampling date (RM-ANOVA; $F_{4,36}=2.69, P=0.046$ for date $\times$ field; Fig. 1f).

\section{Collembola}

With pitfall traps, 29,447 Lepidocyrtus cyaneus, 25,011 Isotoma viridis and 2,516 Entomobrya lanuginosa were captured in all three fields during the three consecutive trapping periods. The abundance of L. cyaneus was lower in mulch plots in field 2 at the first, second and third sampling date (RM-ANOVA; $F_{2,36}=6.32, \quad P=0.004$ for date $\times$ mulch); however, only the latter was significant (Fig. 1g). Abundances of I. viridis were significantly higher in mulch plots in field 1 at the first sampling date but significantly lower in mulch plots in field 2 at the second and third sampling dates (RM-ANOVA; $F_{4,36}=4.89, P=0.003$ for date $\times$ field $\times$ mulch; Fig. 1 h). Abundances of $E$. lanuginosa were significantly higher in field 1 but lower in field 2 at the first sampling date (RM-ANOVA; $F_{4,36}=7.86$, $P<0.001$ for date $\times$ field; Fig. 1i).

${ }^{13} \mathrm{C}$ and ${ }^{15} \mathrm{~N}$ analysis

The $\delta^{15} \mathrm{~N}$ signatures of the 13 soil-dwelling species captured by heat extraction spanned over two trophic levels in the mulch treatment (Fig. 2). The first trophic level comprised decomposers such as the diplopods $P$. inconstans, B. pusillus and B. guttulatus, as well as the Collembola
Onychiurus spp. and sciarid larvae. $\delta^{15} \mathrm{~N}$ signatures of decomposers formed a continuum from 1.0 to $3.1 \%$. The carabid species $T$. quadristriatus was also placed in the decomposer trophic level, with similar $\delta^{15} \mathrm{~N}$ signatures to the diplopod B. guttulatus. The upper trophic level consisted of predators such as the centipedes L. microps and $N$. longicornis and the gamasid mite Pergamasus sp., the Symphyla and the carabid $O$. inustus. Also, $\delta^{15} \mathrm{~N}$ signatures of elaterid larvae were similar to those of predators. In contrast, the sampled elaterid larvae in the no-mulch treatment had a $\delta^{15} \mathrm{~N}$ signature of only $2.9 \%$.

The incorporated maize-borne carbon ranged between $15 \%$ in the Symphyla and $65 \%$ in the diplopod B. pusillus (Fig. 2). The range of percentages of incorporated maizeborne carbon in decomposer species (20-65\%) was similar to that in predator species $(15-56 \%)$.

The $\delta^{15} \mathrm{~N}$ signatures of soil surface species captured by pitfall traps spanned over 6.7 and $7.2 \%$ in the mulch and no-mulch treatment, respectively (Fig. 3). Assuming enrichment in ${ }^{15} \mathrm{~N}$ of about $3 \%$ per trophic level (Minagawa and Wada 1984; Post 2002), the 18 species studied in the no-mulch and the mulch treatments spanned over three trophic levels. In the no-mulch treatment, the two Collembola species $E$. lanuginosa and I. viridis had similar $\delta^{15} \mathrm{~N}$ signatures to the carabids T. quadristriatus and Bembidion obtusum. In the mulch treatment, $\delta^{15} \mathrm{~N}$ signatures of the Collembola E. lanuginosa and I. viridis were $1.1 \%$ $\left(F_{1,3}=4.82, P=0.11\right)$ and $1.4 \%$ o $\left(F_{1,4}=9.03, P=0.040\right)$ lower compared to the no-mulch treatment, thereby building a distinct group with $L$. cyaneus between the two aphid species and the predators. Generally, $\delta^{15} \mathrm{~N}$ signatures of predators were similar in mulch and no-mulch treatments. 
Fig. 3 Mean $\delta^{15} \mathrm{~N}$ values and SD of soil surface dwelling species captured by pitfall traps in the no-mulch (a) and mulch (b) treatments
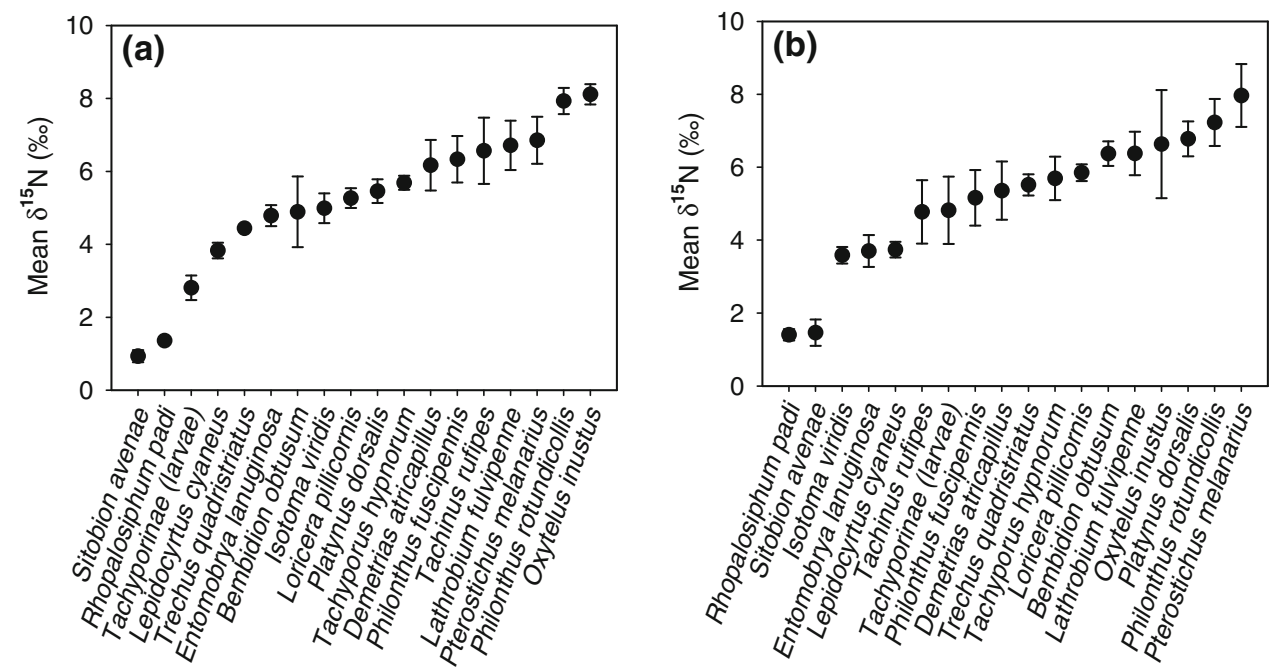

Only 2 of the 18 species of the pitfall catches significantly differed in their $\delta^{13} \mathrm{C}$ signatures between the mulch and the no-mulch treatments. The body of the carabid $T$. quadristriatus $\left(F_{1,4}=26.08, P=0.0070\right)$ and the staphylinid $O$. inustus $\left(F_{1,4}=33.00, P=0.0046\right)$ contained 50 and $49 \%$ of maize-borne carbon, respectively. Interestingly, only these two species were found in both the pitfall traps and the soil cores.

Aphids

The dominant aphid species in all three fields was Sitobion avenae, representing $91.1 \%$ of total aphid numbers, followed by Rhopalosiphum padi (6.3\%) and Metopolophium dirhodum (2.6\%). Aphid infestations averaged 19.8 individuals per shoot, being markedly above the threshold level of economic damage (5 aphids per shoot; Giller et al. 1995). Aphid numbers on wheat plants growing in the pots and wheat plants growing in the field did not differ, nor were there any significant interactions between the factor 'pot' and any of the other factors; the factor 'pot' therefore was eliminated from the statistical model (Table 1).

Total aphid numbers differed significantly between the three fields, with 6- and 22-fold higher aphid numbers in field 1 compared to field 2 and field 3 (Table 1, Fig. 4a). However, predator effects differed significantly between fields. In field 1, aphid numbers were only decreased in plots with both soil-dwelling and flying predators $(-34 \%)$. In field 3, soil-dwelling and flying predators significantly decreased aphid numbers by 80 and $85 \%$, respectively, whereas in field 2 there were no effects on aphid populations in any of the predator treatments. Further, the effect of soil-dwelling and flying predators differed significantly between the mulch and the no-mulch treatments, with the reduction in aphid numbers being restricted to the mulch plots (Table 1, Fig. 4b). In these plots, presence of each
Table 1 ANOVA table of $F$ values for the effect of field $(1,2,3)$, mulch (yes/no), soil dwelling predators (SP; reduced, control) and flying predators (FP; reduced, control) on numbers of aphids per shoot in mid July

\begin{tabular}{lrrl}
\hline Factor & $d f$ & $F$ value & $P$ value \\
\hline Field & $\mathbf{2}$ & $\mathbf{3 7 1 . 0 0}$ & $<\mathbf{0 . 0 0 0 1}$ \\
Mulch & $\mathbf{1}$ & $\mathbf{1 1 . 6 3}$ & $\mathbf{0 . 0 0 1 1}$ \\
SP & $\mathbf{1}$ & $\mathbf{5 . 3 6}$ & $\mathbf{0 . 0 2 3 4}$ \\
FP & $\mathbf{1}$ & $\mathbf{1 4 . 4 0}$ & $\mathbf{0 . 0 0 0 3}$ \\
Field $\times$ mulch & $\mathbf{2}$ & $\mathbf{2 7 . 4 2}$ & $<\mathbf{0 . 0 0 0 1}$ \\
Field $\times$ SP & 2 & 0.20 & 0.8161 \\
Mulch $\times$ SP & $\mathbf{1}$ & $\mathbf{7 . 8 7}$ & $\mathbf{0 . 0 0 6 5}$ \\
Field $\times$ FP & $\mathbf{2}$ & $\mathbf{7 . 6 7}$ & $\mathbf{0 . 0 0 0 9}$ \\
Mulch $\times$ FP & 1 & 0.80 & 0.3751 \\
SP $\times$ FP & 1 & 2.18 & 0.1445 \\
Field $\times$ mulch $\times$ SP & 2 & 2.12 & 0.1272 \\
Field $\times$ mulch $\times$ FP & 2 & 2.28 & 0.1094 \\
Field $\times$ SP $\times$ FP & $\mathbf{2}$ & $\mathbf{3 . 3 2}$ & $\mathbf{0 . 0 4 1 8}$ \\
Mulch $\times$ SP $\times$ FP & $\mathbf{1}$ & $\mathbf{8 . 9 9}$ & $\mathbf{0 . 0 0 3 7}$ \\
Field $\times$ mulch $\times$ SP $\times$ FP & 2 & 0.59 & 0.5600 \\
\hline Si & 2 &
\end{tabular}

Significant effects are marked in bold $\left(d f_{\text {error }}=72\right)$

soil-dwelling and flying predators decreased aphid numbers with the effect being most pronounced in the combined treatment $(-54 \%)$.

\section{Discussion}

Soil food web-maize-borne carbon incorporation

About 9 months after the application of the maize chaff, maize-borne carbon could be detected in all taxa of the sampled soil fauna, indicating ubiquitous utilisation of the mulch material. The percentages of incorporated maize 


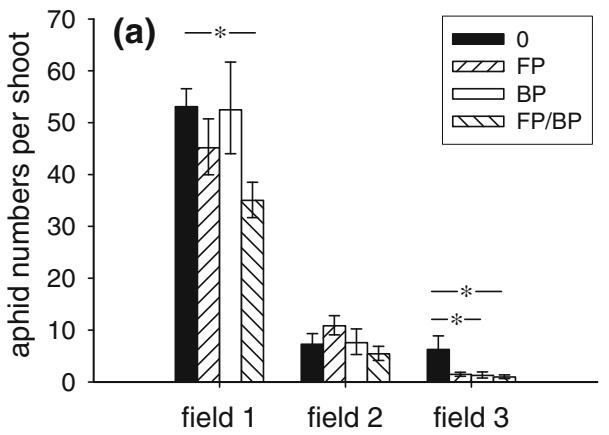

Fig. 4 Aphid populations (given as aphid numbers per shoot) as affected by flying $(F P)$ and soil dwelling predators $(S P)$ in the three different fields (a) and in the no-mulch and mulch treatments (b);

carbon in soil fauna species varied between 15 and $65 \%$, and differed between predators and decomposers. In decomposers, the maize-borne carbon contributed on average $43 \%$ to animal tissue carbon, whereas predators on average contained $34 \%$ maize-borne carbon. This difference in incorporation of maize carbon between trophic groups is similar to that found previously (Albers et al. 2006), and presumably reflects the time lag in carbon incorporation in higher trophic levels.

Assuming a trophic level shift in $\delta^{15} \mathrm{~N}$ signatures of 3\%o (Minagawa and Wada 1984; Post 2002), the soil food web consisted of three trophic levels. Soil food webs in agricultural fields investigated by Moore (1994) varied between 2.3 and 4.2 trophic levels, and Albers et al. (2006) also found three trophic levels in their agricultural soil food web. The $\delta^{15} \mathrm{~N}$ signatures of the species analysed formed a gradient rather than discrete trophic levels. However, the $\delta^{15} \mathrm{~N}$ signatures of the predators spanned only $1.5 \delta^{15} \mathrm{~N}$ units and did not differ between large and small predators, suggesting that predator species consisted of a single trophic level with little evidence for intraguild predation and cannibalism. In contrast, $\delta^{15} \mathrm{~N}$ signatures of decomposers spanned $4.5 \delta^{15} \mathrm{~N}$ units, suggesting that decomposers consist of two trophic levels, i.e. primary and secondary decomposers as indicated earlier (Scheu and Falca 2000; Albers et al. 2006).

Combining the $\delta^{15} \mathrm{~N}$ and $\delta^{13} \mathrm{C}$ signatures may allow identification of trophic links. With similar contents of maize carbon and about $2.5 \delta^{15} \mathrm{~N}$ units higher than the Collembola Onychiurus spp., Symphyla, L. microps and Pergamasus sp. presumably fed on this species; similarly, Albers et al. (2006) assumed Symphyla and Gamasina to prey on Onychiurus spp. As the $\delta^{15} \mathrm{~N}$ signature of elaterid larvae was similar to that of the predatory mite Pergamasus sp. and the centipede $N$. longicornis, they presumably live as predators; recent studies suggest that this is widespread in elaterid larvae (Traugott et al. 2007). Interestingly, $\delta^{15} \mathrm{~N}$ signatures of the diplopod $B$. guttulatus exceeded those of

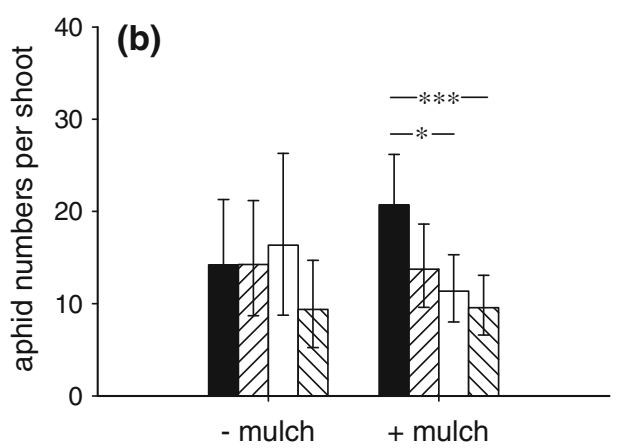

$0=\mathrm{SP}+\mathrm{SF}$ removal, $F P=\mathrm{SP}$ removal, $S P=\mathrm{FP}$ removal, $F P / S P=$ control without predator removal. Error bars indicate SE, significant differences between means are marked $(* P<0.05, * * * P<0.001)$

the other two diplopod species, being similar to the $\delta^{15} \mathrm{~N}$ values of the centipede $L$. microps. As suggested previously, B. guttulatus presumably at least partly lives on an animal diet, e.g. by feeding on carcasses (Hoffman and Payne 1969).

Aboveground food web-maize-borne carbon incorporation

Only two of the sampled species in our study, the carabid $T$. quadristriatus and the staphylinid $O$. inustus, were abundant below- and aboveground as indicated by trapped individuals in both the soil cores and the pitfall traps. Interestingly, only these 2 species incorporated maizeborne carbon, whereas in none of the other 16 species studied, including 13 predators and 3 Collembola species, could maize-borne carbon be detected. This suggests that most predators but also major decomposer taxa such as Collembola did not benefit from increased supply of litter resources. $\mathrm{C} 4$ plants, such as maize, represent low quality food for herbivores and detritivores due to low nitrogen and high fibre content (Caswell and Reed 1976; Boutton et al. 1978; Ehleringer et al. 2001). Omnivory is probably the prevailing feeding strategy in Collembola (Filser 2002); depending on the resources available they ingest bacteria, fungi, algae, plant litter, or other soil animals, such as protozoa, nematodes, rotifers, and enchytraeids (Parkinson 1988; Scheu 2002; Chahartaghi et al. 2005). Potentially, the three epigeic Collembola predominantly fed on algae; at least, they were not linked trophically to the maize carbon pool.

Consistent with the fact that maize-borne carbon did not enter the majority of species of the aboveground food web, the maize mulch affected their $\delta^{15} \mathrm{~N}$ signatures only a little. However, $\delta^{15} \mathrm{~N}$ signatures of the two Collembola species, I. viridis and E. lanuginosa, decreased in the mulch plots, thereby placing them between the two aphid herbivores and the predators. Presumably, the Collembola species 
increased feeding on more basal food sources, potentially algae with low $\delta^{15} \mathrm{~N}$ signatures. Some predator taxa showed similar decreases in their $\delta^{15} \mathrm{~N}$ signatures, but not significantly; still, this suggests that these predators mainly feed on Collembola. Further, $\delta^{15} \mathrm{~N}$ signatures of all predator species in both the no-mulch (except for the Tachyporinae larvae) and the mulch treatments more than $3 \%$ higher than those of the two aphid species is consistent with a mixed diet consisting of Collembola and aphids. Including Collembola and aphids in mixed diets improves development, survival and egg production of generalist predators (Toft 1995; Borg and Toft 1999; Bilde et al. 2000; Oelbermann and Scheu 2002), and complementary predation on aphids and Collembola was previously shown in a field experiment in winter wheat (von Berg et al. 2009).

Effects of mulch on predator densities and feedbacks on aphid suppression

Of the 34 carabid beetle species identified, only 1 species (T. quadristriatus) was significantly increased in density in the mulch treatment. Furthermore, out of the 12 sampled staphylinid genera, the density of only 2 species ( $P$. fuscipennis and $O$. inustus) were significantly increased in the mulch treatment. Except $P$. fuscipennis, these species incorporated maize-borne carbon, suggesting that they in fact benefited from the maize resource, presumably through feeding on decomposer prey, most importantly Collembola. Additionally, the densities of carabid and staphylinid larvae, and 'Collembola feeders', were increased in the mulch treatment. However, the effect of mulch on these taxa as well as on the staphylinid $P$. fuscipennis likely was indirect rather than through predation on decomposer prey as no maize-borne carbon was detected in these taxa. Thomas et al. (2002) suggested that mobile species are able to respond rapidly to changing environmental conditions and food availability, and different soil textures likely influence oviposition, larval development and survival. Furthermore, enhanced prey availability triggers predator aggregation (Niemela et al. 1986; Kielty et al. 1996; Bohan et al. 2000), and our mulch application presumably increased prey species, as maize carbon was used as additional resource by decomposer soil invertebrates. Therefore, enhanced densities in larvae of staphylinid and carabid beetles in our mulch treatment indicate that these taxa had been attracted to these sites and may have contributed to the observed reduction in aphid populations. Addition of mulch may therefore also enhance the control of pest species by attracting predators; once attracted, they may contribute to pest control without benefiting from prey out of the decomposer system. In fact, generalist predators in arable fields such as carabid beetles are highly mobile and shift habitats from one generation to the next (Thomas et al. 1998).
Despite the apparently minor effect of maize mulch on predator densities, aphid numbers were significantly reduced by generalist predators in the mulch treatment. Reducing aphid numbers may have been due to generalist predators climbing the plants and also by feeding on aphids dislocated by rain onto the soil surface (von Berg et al. 2009). As only a few predator species were affected by maize mulch, control of aphid populations were likely due to these predators, i.e. P. fuscipennis, $O$. inustus and T. quadristriatus, as well as to carabid and staphylinid larvae. Interestingly, effects of maize mulch on densities of these predators differed significantly between fields. Moreover, only in two (field 1 and 3) out of the three investigated fields, aphid populations were significantly decreased by generalist predators. Lack of aphid control in field 2 may have been due to less pronounced colonisation of this field by $P$. fuscipennis from adjacent fields as field 2 was closer to the city of Göttingen with fewer fields in its surroundings as compared to fields 1 and 3 .

By combining the data of field-specific effects of mulch on predator densities and predator effects on aphid populations, single predator species can be identified as most effective control agents. With significant predator effects on aphid populations in mulch plots in field 1 and simultaneously increased densities of the staphylinid $P$. fuscipennis exclusively in mulch plots in this field, this species most likely contributed to the significant aphid suppression in this field. Using molecular gut content analyses, $P$. fuscipennis is known to consume aphids at high rates $(\mathrm{K}$. von Berg, unpublished data). Furthermore, this species may effectively control aphid populations as indicated in previous field studies (Sopp and Wratten 1986; Dennis and Wratten 1991). In the other field (field 3) where soil dwelling predators effectively suppressed aphid populations in mulch plots $(-80 \%)$, densities of $P$. fuscipennis were negligible. In this field, densities of T. quadristriatus and $O$. inustus likely contributed to aphid control, as their densities were significantly increased in the mulch plots. T. quadristriatus preys on aphids (Sunderland et al. 1987; Mundy et al. 2000), and O. inustus, a species which is very common in agricultural fields (Krooss and Schaefer 1998; Markgraf and Basedow 2002), is carnivorous (Eghtedar 1970). Interestingly, densities of these two species were also increased in field 2; however, no effects on aphid populations were observed. Failure in aphid suppression has been recorded in some field studies (Holland et al. 1996; Holland and Thomas 1997; Collins et al. 2002). Generally, aphid control is assumed to be most effective early in the season (Edwards et al. 1979; Chiverton 1986) and densities of T. quadristriatus in field 2 were most increased at the second and third sampling dates when aphid populations may have escaped predator control. The effect of carabid and staphylinid larvae is difficult to predict as they were not 
determined to species level and likely constitute of a number of species. Several carabid and staphylinid larvae have been documented to prey on aphids (Sunderland et al. 1987; Dennis et al. 1991; Kollat-Palenga and Basedow 2000; Kyneb and Toft 2004) and, therefore, the increased density of these larvae likely contributed to aphid suppression in our study.

\section{Conclusions}

The present study demonstrated the incorporation of detrital food resources (maize chaff) into an agricultural soil food web. Certain predator species of the aboveground system incorporated maize-borne carbon via prey out of the decomposer system thereby significantly increasing in density in the mulch treatment. Effects of the added detritus propagated via generalist predators into the herbivore system, as predators significantly decreased aphid populations in mulch fields. Predator and herbivore densities as well as effects of mulch addition varied strongly between fields emphasising the necessity to investigate multitrophic interactions in a landscape context. Further, the results suggest that single generalist predator species can significantly contribute to herbivore suppression in agricultural systems, and these effects may be fostered by residue management practices. Knowledge on the factors driving the population dynamics of these species therefore allows development of management practices which improve conservation biological control.

Acknowledgments We are indebted to R. Langel (University of Göttingen) for stable isotope measurements. This study was supported by the German Science Foundation (DFG).

Open Access This article is distributed under the terms of the Creative Commons Attribution Noncommercial License which permits any noncommercial use, distribution, and reproduction in any medium, provided the original author(s) and source are credited.

\section{References}

Albers D, Schaefer M, Scheu S (2006) Incorporation of plant carbon into the soil animal food web of an arable system. Ecology 87:235-245

Bell JR, Traugott M, Sunderland KD, Skirvin DJ, Mead A, KravarGarde L, Reynolds K, Fenlon JS, Symondson WOC (2008) Beneficial links for the control of aphids: the effects of compost applications on predators and prey. J Appl Ecol 45:1266-1273

Bilde T, Axelsen JA, Toft S (2000) The value of Collembola from agricultural soils as food for a generalist predator. J Appl Ecol 37:672-683

Birkhofer K, Wise D, Scheu S (2008) Dual-subsystem omnivory, but not microhabitat complexity affects the role of generalist predators in an aboveground herbivore food web. Oikos 117:494-500
Bohan DA, Bohan AC, Glen DM, Symondson WOC, Wiltshire CW, Hughes L (2000) Spatial dynamics of predation by carabid beetles on slugs. J Anim Ecol 69:367-379

Borg C, Toft S (1999) Value of the aphid Rhopalosiphum padi as food for grey partridge Perdix perdix chicks. Wildl Biol Pract 5:55-58

Boutton TW, Cameron GN, Smith BN (1978) Insect herbivory on C-3 and C-4 grasses. Oecologia 36:21-32

Caswell H, Reed FC (1976) Plant-herbivore interactions - indigestibility of C-4 bundle sheath-cells by grasshoppers. Oecologia 26:151-156

Chahartaghi M, Langel R, Scheu S, Ruess L (2005) Feeding guilds in Collembola based on nitrogen stable isotope ratios. Soil Biol Biochem 37:1718-1725

Chiverton PA (1986) Predator density manipulation and its effects on populations of Rhopalosiphum padi (Hom, Aphididae) in spring barley. Ann Appl Biol 109:49-60

Cole JW, Grizzle JE (1966) Applications of multivariate analysis of variance to repeated measurements experiments. Biometrics 22:810-828

Collins KL, Boatman ND, Wilcox A, Holland JM, Chaney K (2002) Influence of beetle banks on cereal, aphid predation in winter wheat. Agric Ecosyst Environ 93:337-350

DeNiro MJ, Epstein S (1981) Influence of diet on the distribution of nitrogen isotopes in animals. Geochim Cosmochim Acta 45:341351

Dennis P, Wratten SD (1991) Field manipulation of populations of individual staphylinid species in cereals and their impact on aphid populations. Ecol Entomol 16:17-24

Dennis P, Wratten SD, Sotherton NW (1991) Mycophagy as a factor limiting predation of aphids (Hemiptera, Aphididae) by staphylinid beetles (Coleoptera, Staphylinidae) in cereals. Bull Entomol Res 81:25-31

Edwards CA, Sunderland KD, George KS (1979) Studies on polyphagous predators of cereal aphids. J Appl Ecol 16:811-823

Eghtedar E (1970) Biology and ecology of Staphylinidae Philonthys fuscipennus Mannh and Oxytelus rugosus Grav. Pedobiologia 10:169-179

Ehleringer JR, Cering TE, Flanagan LB (2001) Global change and the linkages between physiological ecology and ecosystem ecology. In: Press MC, Huntly MC, Levin S (eds) Ecology: achievement and challenge. Blackwell, Oxford, pp 115-138

Filser J (2002) The role of Collembola in carbon and nitrogen cycling in soil. Pedobiologia 46:234-245

Fry B, Jeng WL, Scalan RS, Parker PL, Baccus J (1978) C-delta-13 food web analysis of a Texas sand dune community. Geochim Cosmochim Acta 42:1299-1302

Giller PS, Ryan B, Kennedy T, Connery J (1995) Aphid-parasitoid interactions in a winter cereal crop-field trials involving insecticide application. J Appl Entomol 119:233-239

Hairston NG Jr (1989) Ecological experiments: purpose design and execution. Cambridge University Press, Cambridge

Hairston NG, Smith FE, Slobodkin LB (1960) Community structure, population control, and competition. Am Nat 94:421-425

Halaj J, Wise DH (2002) Impact of a detrital subsidy on trophic cascades in a terrestrial grazing food web. Ecology 83:3141-3151

Hoffman RL, Payne JA (1969) Diplopods as carnivores. Ecology 50:1096-1098

Holland JM, Thomas SR (1997) Assessing the role of beneficial invertebrates in conventional and integrated farming systems during an outbreak of Sitobion avenae. Biol Agric Hortic 15:73-82

Holland JM, Thomas SR, Hewitt A (1996) Some effects of polyphagous predators on an outbreak of cereal aphid (Sitobion avenae F) and orange wheat blossom midge (Sitodoplosis mosellana Gehin). Agric Ecosyst Environ 59:181-190

Kempson D, Lloyd M, Ghelardi R (1963) A new extractor for woodland litter. Pedobiologia 3:1-21 
Kielty JP, Allen-Williams LJ, Underwood N, Eastwood EA (1996) Behavioral responses of three species of ground beetle (Coleoptera: Carabidae) to olfactory cues associated with prey and habitat. J Insect Behav 9:237-250

Kollat-Palenga I, Basedow T (2000) Aphid feeding of predatory Staphylinidae on different strata (soil surface and wheat seedlings) in laboratory experiments. J Plant Dis Prot 107:643-648

Krooss S, Schaefer M (1998) The effect of different farming systems on epigeic arthropods: a five-year study on the rove beetle fauna (Coleoptera: Staphylinidae) of winter wheat. Agric Ecosyst Environ 69:121-133

Kyneb A, Toft S (2004) Quality of two aphid species (Rhopalosiphum padi and Sitobion avenae) as food for the generalist predator Tachyporus hypnorum (Col., Staphylinidae). J Appl Entomol 128:658-663

Lang A (2003) Intraguild interference and biocontrol effects of generalist predators in a winter wheat field. Oecologia 134:144-153

Lövei GL, Sunderland KD (1996) Ecology and behavior of ground beetles (Coleoptera: Carabidae). Annu Rev Entomol 41:231-256

Markgraf A, Basedow T (2002) Flight activity of predatory Staphylinidae in agriculture in central Germany. J Appl Entomol 126:79-81

Martin A, Mariotti A, Balesdent J, Lavelle P (1992) Soil organic matter assimilation by a geophagous tropical earthworm based on $\delta^{13} \mathrm{C}$ measurements. Ecology 73:118-128

Minagawa M, Wada E (1984) Stepwise enrichment of N-15 along food-chains - further evidence and the relation between deltaN-15 and animal age. Geochim Cosmochim Acta 48:1135-1140

Moore JC (1994) Impact of agricultural practices on soil food-web structure-theory and application. Agric Ecosyst Environ 51:239-247

Mundy CA, Allen-Williams LJ, Underwood N, Warrington S (2000) Prey selection and foraging behaviour by Pterostichus cupreus L. J Appl Entomol 124:349-358

Niemela J, Haila Y, Ranta E (1986) Spatial heterogeneity of carabid beetle dispersion in uniform forests on the Aland Islands, SW Finland. Ann Zool Fenn 23:289-296

Oelbermann K, Scheu S (2002) Effects of prey type and mixed dites on survival, growth and development of a generalist predator, Pardosa lugubris (Araneae: Lycosidae). Basic Appl Ecol 3:285-291

Parkinson D (1988) Linkages between resource availability, microorganisms and soil invertebrates. Agric Ecosyst Environ 24:21-32

Peterson BJ, Fry B (1987) Stable isotopes in ecosystem studies. Annu Rev Ecol Syst 18:293-320

Polis GA (1991) Complex trophic interactions in deserts-an empirical critique of food-web theory. Am Nat 138:123-155

Polis GA (1994) Food webs, trophic cascades and community structure. Aust J Ecol 19:121-136

Polis GA, Strong DR (1996) Food web complexity and community dynamics. Am Nat 147:813-846

Polis GA, Myers CA, Holt RD (1989) The ecology and evolution of intraguild predation-potential competitors that eat each other. Annu Rev Ecol Syst 20:297-330

Pollierer M, Langel R, Körner C, Maraun M, Scheu S (2007) The underestimated importance of belowground carbon input for forest soil animal food webs. Ecol Lett 10:729-736

Ponsard S, Arditi R (2000) What can stable isotopes (delta N-15 and delta C-13) tell about the food web of soil macro-invertebrates? Ecology 81:852-864

Post DM (2002) Using stable isotopes to estimate trophic position: models, methods, and assumptions. Ecology 83:703-718

Potvin C, Lechowicz MJ, Tardif S (1990) The statistical analysis of ecophysiological response curves obtained from experiments involving repeated measures. Ecology 71:1389-1400

Reineking A, Langel R, Schikowski J (1993) N-15, C-13-on-line measurements with an elemental analyzer (Carlo-Erba, Na-1500), a modified trapping box and a gas isotope mass-spectrometer (Finnigan, Mat-251). Isotopenpraxis 29:169-174

Scheu S (2001) Plants and generalist predators as links between the below-ground and above-ground system. Basic Appl Ecol 2:3-13

Scheu S (2002) The soil food web: structure and perspectives. Eur J Soil Biol 38:11-20

Scheu S, Falca M (2000) The soil food web of two beech forests (Fagus sylvatica) of contrasting humus type: stable isotope analysis of a macro- and a mesofauna-dominated community. Oecologia 123:85-296

Scheu S, Schaefer M (1998) Bottom-up control of the soil macrofauna community in a beechwood on limestone: manipulation of food resources. Ecology 79:1573-1585

Settle WH, Ariawan H, Astuti ET, Cahyana W, Hakim AL, Hindayana D, Sri Lestari A, Sartanto P (1996) Managing tropical rice pests through conservation of generalist natural enemies and alternative prey. Ecology 77:1975-1988

Snyder WE, Wise DH (2001) Contrasting trophic cascades generated by a community of generalist predators. Ecology 82:1571-1583

Sopp P, Wratten SD (1986) Rates of consumption of cereal aphids by some polyphagous predators in the laboratory. Entomol Exp Appl 41:69-73

Stiger TR, Kosinski AS, Barnhart HX, Kleinbaum DG (1998) ANOVA for repeated ordinal data with small sample size? A comparison of ANOVA, MANOVA, WLS and GEE methods by simulation. Comm Stat Simulat Comput 27:357-375

Sunderland KD, Crook NE, Stacey DL, Fuller BJ (1987) A study of feeding by polyphagous predators on cereal aphids using ELISA and gut dissection. J Appl Ecol 24:907-933

Symondson WOC, Sunderland KD, Greenstone MH (2002) Can generalist predators be effective biocontrol agents? Annu Rev Entomol 47:561-594

Thiele HU (1977) Carabid beetles in their environments. Springer, Berlin

Thomas CFG, Parkinson L, Marshall EJP (1998) Isolating the components of activity-density for the carabid beetle Pterostichus melanarius in farmland. Oecologia 116:103-112

Thomas CFG, Holland JM, Brown NJ (2002) The spatial distribution of carabid beetles in agricultural landscapes. In: Holland JM (ed) The agroecology of carabid beetles. Intercept, Andover, pp 305344

Toft S (1995) Value of the aphid Rhopalosiphum padi as food for cereal spiders. J Appl Ecol 32:552-560

Toft S (2005) The quality of aphids as food for generalist predators: implications for natural control of aphids. Eur $\mathbf{J}$ Entomol 102:371-383

Traugott M, Pazmandi C, Kaufmann R, Juen A (2007) Evaluating $\mathrm{N}-15 / \mathrm{N}-14$ and $\mathrm{C}-13 / \mathrm{C}-12$ isotope ratio analysis to investigate trophic relationships of elaterid larvae (Coleoptera: Elateridae). Soil Biol Biochem 39:1023-1030

Von Berg K, Thies C, Tscharntke T, Scheu S (2009) Cereal aphid control by generalist predators in presence of belowground alternative prey: complementary predation as affected by prey density. Pedobiologia 53:41-48

Weinreich R (1968) Über den Klebfangapparat der Imagines von Stenus Latr. (Coleopt, Staphylinidae) mit einem Beitrag zur Kenntnis der Jugendstadien dieser Gattung. Z Morph Ökol Tiere 62:162210

Wise DH (1993) Spiders in ecological webs. Cambridge University Press, New York

Wise DH (2006) Cannibalism, food limitation, intraspecific competition and the regulation of spider populations. Annu Rev Entomol 51:441-465 